\title{
O Corpo, o mito, a crueldade e a criação: a tradição de si mesmo no trabalho do ator- criador
}

The Body, the myth, the cruelty and the creation: the tradition of oneself in the work of the actor-creator

Mariane Magno Ribas ${ }^{1}$ 


\section{Resumo}

Este texto propõe a aproximação possível de diferentes vertentes de conhecimento que observam o Corpo em certo estado criativo aflorado de sua materialidade psicossomática viva, isto é, a vivência do sagrado em um corpo trabalhado e sensível; o qual possui organizações múltiplas, justapostas, complexas e vivas que compreendemos como indispensáveis à vivência da imaginação poética no ator-criador, sendo tal elaboração corporal o ponto de convergência deste pensamento, $\mathrm{O}$ ator como a tradição de si mesmo.

Palavras-chave: Teorias da atuação; treinamento; corpo sagrado

\section{Abstract}

This text proposes the possible approachximatiom of to different sources of knowledge that observe the Body in certain creative state emerged from its the vivacious psychosomatic materiality, i.e., the experience of the sacred in a worked trained and sensitive body; which has multiple, joined, complex and vivacious organizations that are understood as essential to the actor-creator poetic imagination experience by the actor-creator. Its bodily elaboration is the point of convergence in this thinking, the tradition of the actor as oneself.

Keywords: Acting theory; training; sacred body. 
1. O Corpo, a tradição, a crueldade e a criação

O Corpo é uma multidão excitada, uma espécie de caixa de fundo falso que nunca mais acaba de revelar o que tem dentro.

E tem dentro toda a realidade.

Querendo isto dizer que cada indivíduo existente é tão grande como a imensidão inteira, e pode ver-se na imensidão inteira (Artaud, 1947 apud Quilici, 2004, p. 197).

Partimos desta epígrafe para apresentar o sentido do arquétipo vivo no Corpo² ao qual iremos nos aproximar. Fica definida, portanto, como condição para a existência deste certo Corpo poético, a força que nos é dada pela consciência psicofísica da tradição, cujo movimento atua sob potências arquetípicas através de exercícios e de treinamentos das faculdades imaginativas, criativas, somáticas, críticas, intelectuais e sensíveis ${ }^{3}$, no Ser ator.

Não a tradição entendida como o peso do passado, daqueles que querem impor o seu modo de viver, mas a tradição como força de poder mudar sem nos tornarmos caos, de continuarmos iguais sem nos tornarmos mortos, isto é, em última análise, de viver. Tradição e vida são sinônimos, se vocês pensarem bem nisso, Artaud disse isso (Ruffini, 2000, p. 57).

O entendimento de Corpo do qual nos aproximaremos com esta escrita é o de um corpo trabalhado e treinado, capaz de manter vivo o trabalho sobre si mesmo; por conseguinte, um corpo inteligente e sensível. Um corpo que é "vivo" porque sabe como atuar (aspectos objetivos) ao mesmo tempo em que também sabe como 'se permitir ser atuado' (compreensões sensíveis e instintivas a cada vez) sob a imaginação, em certo espaço e durante certo tempo, à luz dos direcionamentos cênicos. Em outras palavras, trata-se da elaboração e do agir conjunto entre a sensibilidade interna e a sensibilidade externa, por Stanislávski perezhivanie e personificação. Mas, da união dessas polaridades, "o que importa é a síntese e não a soma" (Ruffini s/d apud Barba \& Savarese, 1995, p. 151).

Sobre tais relações e direcionamentos estéticos entre a materialidade interna e a externa, podemos falar, ainda, de modo bem mais amplo. O que importa, de fato, é a fusão que estabelece um eixo vivo cuja dinâmica plástica, a partir deste centro, atua sob os direcionamentos de uma certa ação conjunta. Isto quer dizer que este eixo vivo, a ação conjunta, só acontece quando as relações estabelecidas como ação central, fundem, criativamente, os conteúdos conscientes e a materialidade que emerge do inconsciente, ou seja, do Corpo, a cada vez e em função da ação. Esta fusão criativa é o eixo vivo do trabalho do ator. Mas, para a dinâmica deste eixo se manter viva

${ }^{2}$ As teorias posteriores de Jung sobre 0 arquétipo apontavam para uma explicação psicossomática. Os arquétipos podem ser considerados ligando o corpo instinto e a psique imagem. Instintos e imagens possuem a mesma raiz psicoide. Daí, em vez de desvalorizar o corpo, Jung percebia que suas ideias o revalorizavam e davam um novo ponto de vista ao relacionamento de um indivíduo com a psicologia coletiva. Esta última poderia ser compreendida como se expressando no corpo e através dele, que, por ser comum a todos, pode ser considerado em termos gerais como o lugar central do inconsciente coletivo (Stevens, 1982, apud Samuels et al., 1988). O corpo pode ser considerado uma expressão da "materialidade física da psique"
(CW 9 i, parág. 392). 0 que o corpo faz, experimenta, necessita todos estes aspectos refletem imperativos psicológicos. 0 corpo então pode ser considerado como um "corpo sutil". Um exemplo da importância psicológica de imagens corporais pode ser encontrado em motivos da ressurreição ou renascimento. Um outro seria o modo como imagens sexuais têm seu próprio significado psicológico. (Samuels et al., 1988).

${ }_{3}$ Importa é que, através de meios seguros, a sensibilidade seja colocada num estado de percepção mais aprofundada e mais apurada, é esse 0 objetivo da magia e dos ritos, dos quais o teatro é apenas um reflexo (Artaud, 1999, p. 104). 
é preciso saber que: "o processo de dar forma é sempre um compromisso que temos que aceitar, dizendo ao mesmo tempo; é provisória, tem que ser renovada. Trata-se de uma dinâmica que nunca terá fim" (Brook, 1999, p. 45).

Tais condições (precisão e organicidade) e dimensões psicofísicas (arquetípica, mitológica e universal) quando exercitadas e ativas nos treinamentos ou nos processos criativos, englobam, de forma conjunta, tanto a materialidade individual (corpo biológico) quanto a universal (corpo sutil, corpo como arquétipo, corpo como mito e corpo poético); tanto os aspectos racionais quanto os instintivos e sensuais. Para tamanha jornada, pressupõe-se coragem para agir; coragem que é possível ser elaborada e vivenciada sob o exercício do querer e da consciência, durante certo tempo em treinamento sistematizado, inteligente, crítico e sensível, no qual, treinamento, o ator pode criar diálogos vivos no eixo ego-self4 corporal. "É o corpo treinado do ator que lhe garante permanecer idêntico, porém mudando a cada vez, como a lua, como um fenômeno da natureza. É essa a emoção que sentimos diante dos grandes mestres" (Ruffini, 2000, p. 57).

Retomaremos a coragem para agir, apontada no parágrafo anterior, todavia, antes, é preciso retornar a sua nascente, que é também o seu oposto complementar, isto é, retornar ao medo. O medo como consciência psicofísica, consciente ou não, e não apenas como significado. Trata-se, por conseguinte, do medo que habita o território sensível, ou seja, como experiência e não predominantemente na esfera semântica.

São diversos os tipos de medo 5 e, entre eles, existem diferentes dimensões como, por exemplo, os medos conscientes dos perigos e dos riscos imanentes em cada processo criativo. Estes medos são familiares e previsíveis, advêm das dimensões do ego e afloram quando em face ao desconhecido. Nesta dimensão incluímos ainda outros medos previsíveis, como o de cometer equívocos, o medo da cegueira, o medo da incompreensão; ou, além desses, o descorado medo de "não dar tempo". Neste último, às vezes, tal expressão é apenas manifestação da ansiedade latente ou da fala comum, acostumada e estereotipada, e que, neste caso, já é outra coisa (mas isso já é outro assunto, o qual não será tratado aqui). Estamos, portanto, ainda nos conteúdos da dimensão familiar, previsível e consciente. Porém, existem medos mais vivos e bem mais físicos, como o medo que aflora, como que por si mesmo, na musculatura e estabelece um estado psicofísico correspondente e aparentemente

\begin{abstract}
${ }^{4}$ SELF: arquétipo da totalidade e o centro regulador da psique; poder transpessoal que transcende o ego (Sharp, 1997, p. 142). Como todo arquétipo, a natureza essencial do self é incognoscivel, mas suas manifestações são o conteúdo de mitos e lendas. [...] Como conceito empírico, o self designa toda a gama de fenômenos psíquicos do homem. [...] abrange tanto aquilo que é passível de experiência, quanto aquilo que não o é (ou aquilo que não foi ainda objeto da experiência)... É um conceito transcendente, pois pressupõe a existência de fatores inconscientes com bases empíricas, caracterizando, assim, uma entidade que pode ser descrita apenas em parte. As experiências do self possuem uma numinosidade, característica das revelações religiosas. Por isso, Jung acreditava que não havia nenhuma diferença essencial entre 0 self enquanto realidade experimental e psicológica e o conceito tradicional de uma divindade suprema (Sharp, 1991, pp. 142-143). "O self não é somente o centro, mas também a circunferência total, que abarca tanto o consciente
\end{abstract}

quanto o inconsciente; é o centro desta totalidade, assim como o ego é o centro da consciência" (Jung, 1953-1979 apud arp, 1991, p. 142).

${ }^{5}$ Segundo Campbell o medo, no mito do herói é um dos grandes obstáculos interiores a ser superado pelos jovens (desde as civilizações mais primitivas) em rituais de passagem à vida adulta (amadurecimento). 0 medo integrado às estruturas psíquicas do ser humano nos aproxima do medo como energia psíquica, isto é como conteúdo vivo e presente em todo ser humano (Jung). "No âmbito psicanalítico o medo é interpretado como emoção primária de defesa diante de uma condição de perigo que pode ser real, antecipada através de uma previsão, evocada por uma lembrança, ou então produzida pela atividade fantástica. [...] 0 medo é fundamentalmente interpretado como necessário à constituição tanto da consciência moral como da assim chamada consciência gnosiológica, isto é, da consciência do funcionamento da própria consciência" (Pieri, 2002, p. 313). 
inexplicável e, este estado, é possível ser reconhecido e visualizado no corpo "travado" como, por exemplo, quando o ator diz querer agir, mas, mesmo assim, o seu corpo não responde porque está fechado à dinâmica da percepção e preso às suas tensões. O corpo também é território do inconsciente (Campbell, Keleman, Jung, Brook, Grotowski, Artaud) e, neste caso, entre o querer agir e o agir há um caminho a ser criado (descoberto) e percorrido em si e sobre si mesmo. Há também o medo do enfrentamento e o medo do choque

de confrontar a si mesmo perante desafios simples e irrefutáveis. O choque de perceber seus próprios subterfúgios, truques e clichês. O choque de intuir a potencialidade inexplorada de seus amplos recursos. $\mathrm{O}$ choque de ser forçado a questionar sua opção como ator. $\mathrm{O}$ choque de ter que admitir que essas questões existem e que [...] há um momento em que elas tem que ser encaradas; e de descobrir que quer encará-las. O choque de saber que existe um lugar no mundo onde a interpretação é uma arte cultivada com dedicação absoluta monástica e total. Embora tenha virado chavão, a expressão de Artaud, 'cruel consigo mesmo' é um autêntico modo de vida - em algum lugar - para cerca de dez pessoas (Brook, 1995 p. 62).

Há, ainda, uma dimensão mais ampla, na qual identificamos o grande medo mitológico, aquele que sabemos indispensável à coragem do agir heroico. E, entre tantos medos que conhecemos e que são possíveis de nomear, há outros, ainda maiores e mais profundos, eles têm um sentido imenso que vai além do semântico, é um sentido que ultrapassa o ser, isto é, o medo profundo misterioso e assombroso no Ser.

Queremos ainda dizer que estes medos profundos habitam, 'povoam', as estruturas da psique e, consequentemente, as estruturas físicas e vivas no corpo. Estamos nos referindo ao medo do grande mistério morte-vida, ao medo arcaico e primitivo da imensidão do cosmos. E, junto a estas estruturas arquetípicas e arcaicas, também vivem os medos mais recentes e existenciais, como por exemplo, o medo filosófico da prisão na pequenez do Ser. Estes medos, e outros tantos, estão mais ou menos adormecidos ou ativados em cada ser e em cada momento; porém, sabê-los, trabalhá-los, é decisão de cada um.

A coragem para agir, necessária ao ato criativo, cuja raiz está em certa percepção do medo, não é, por conseguinte, a coragem cega, inconsequente e caótica, mas, sim, a coragem que nasce e é elaborada a partir da percepção e das relações conscientes com o medo e que se processa pelos procedimentos. É a partir dessa percepção que é possível construir a confiança e o respeito que advém do trabalho psicotécnico de cada ator, em si e sobre si mesmo. Brook (1999) fala do ator afinado (treinado) pelos exercícios que libertam das tensões e hábitos desnecessários: assim, o ator

fica pronto para abrir-se as ilimitadas possibilidades do vazio. Mas há um preço a pagar: diante do vazio desconhecido surge, naturalmente, o medo. [...] medo do vazio dentro de si mesmo e do vazio no espaço. Imediatamente ele trata de preencher o vazio para livrar-se do medo, tentando achar alguma coisa para dizer ou fazer. Sentar-se imóvel ou ficar quieto requer muita coragem. A maioria das nossas manifestações exageradas ou desnecessárias provém do pavor de não estarmos realmente presentes se não avisarmos o tempo todo, de qualquer jeito, que de fato existimos. [...] no teatro, onde todas as energias devem convergir para o mesmo fim, a capacidade de reconhecer que se pode estar totalmente presente, embora aparentemente sem "fazer" nada, é fundamental (Brook, 1999, p. 18). 
O trabalho psicotécnico fundamenta-se, portanto, no conhecimento deixado pelos mestres que fundaram e/ou deram continuidade na tradição dinâmica do treinamento corporal (psicotécnico) para o ator. Esta dinâmica, a da tradição do treinamento, move-se junto a um eixo maior, o da tradição teatral; isto é, a coragem elaborada e direcionada é um dos nutrientes vivos e indispensáveis, cuja ação, da coragem, vem atravessando séculos e gerando força ao ato sensível, poético, crítico e cênico.

O movimento e as relações entre o medo e a coragem, por conseguinte, também movem tanto a tradição do treinamento quanto a tradição teatral em sua dinâmica viva, necessária à contínua mutabilidade artística. Ao utilizar a imagem do esforço, da dedicação e da atenção, de um alpinista, necessários à escalada, como uma imagem viva para o entendimento (racional e mitológico) do trabalho indispensável à jornada do ator, Mnouchkine responde:

[...] o que um ator deve trazer na bagagem para escalar a montanha? Coragem. Muitíssima coragem, paciência, e, talvez, necessidade de elevação. E, quando digo necessidade de elevação, obviamente não estou querendo dizer de celebridade ou de glória. Um ator e uma atriz só escalarão uma montanha se tiverem necessidade de poesia, de amplidão, de superação, em suma, do humano. [...] Quer dizer um corpo o mais livre possível, o mais treinado possível, mas também imaginação, uma imaginação tão livre e treinada quanto possível (Mnouchkine 1992 apud Féral, 2010, p. 86).

Artaud (1999) em uma de suas cartas, escrita em setembro de 1932, chamou de crueldade a percepção consciente, o empenho e o esforço indispensáveis à criação viva, a qual também pode ser chamada de verdadeira por sua materialidade psicossomática; isto é, pelo enraizamento somático elaborado pela linguagem expressa esteticamente.

Não se trata de crueldade, nem de sadismo, nem de sangue, pelo menos de modo exclusivo. [...] Do ponto de vista do espírito a crueldade significa rigor, aplicação e decisão implacáveis, determinação irreversível, absoluta. O determinismo filosófico mais comum é, do ponto de vista de nossa existência, uma das imagens da crueldade. [...] A crueldade é antes de mais nada lúcida, é uma espécie de direção rígida, submissão à necessidade. Não há crueldade sem consciência, sem uma espécie de consciência aplicada (Artaud, 1999, p. 118).

A tradição teatral é, portanto, um eixo vivo que move as forças criativas, cuja materialidade plástica, de tais forças, emerge das suas leis universais, sob seus ensinamentos e a partir de seus fundamentos e princípios, trabalhados e vividos sob a crueldade, os quais vêm sendo deixados, generosamente, pelos grandes mestres, por meio de suas imensas existências, pesquisas, criações e reflexões. Não há como se desconectar da tradição porque

[...] estamos falando da vida. O que é aquela coisa que permanece a mesma, mas, ao mesmo tempo, continuamente muda? É a vida. Todos vocês atravessaram a puberdade. Ela é igual para todos, mas é diferente para todos. Há uma outra coisa que possui essa propriedade: é a tradição. Não se deve confundir tradição com cerimonial. O cerimonial é tradição quando se torna morta, quando fazemos porque todos a fazem, é a forma da tradição sem a alma dentro [...]. Na tradição, tudo permanece igual, mas cada vez que aparece, é como se fosse a primeira vez (Ruffini, 2000, p. 56). 
Tais princípios, os da grande tradição teatral, se renovam e ganham materialidade quando fundamentam os procedimentos técnico-expressivos atuais e movem cada ator de modo individual e privado. É, portanto, no agir conjunto entre os princípios, os procedimentos, o senso crítico, a ética, o senso estético e a atenção no presente que compreendemos a possibilidade de um caminho singular para elaboração e direcionamento específico do trabalho criativo do ator e da sua coragem para agir, em si e sobre si mesmo, a cada vez.

Estamos falando de uma das funções do treinamento. E treinamento é uma tradição que também pode ser observada há muito tempo, como, por exemplo, no século XV, na commedia dell'arte, para a preservação de sua linguagem específica e de seu repertório corporal (acrobacias, gestos, posturas, personalidade, etc.), assim como de seus signos corporais (que determinavam cada personagem) e códigos de atuação (em cena) como a triangulação e os bordões. Neste caso, o treinamento permite o improviso que gera a vida sem ser caótico. Ao entrar no edifício teatral, século XVIII, e ganhar um texto dramático pela primeira vez, de Goldoni, a commedia dell'arte mudou, e também permaneceu a mesma. Por outro lado, treinamento atualmente também é uma terminologia bastante utilizada e que, às vezes, é tratada de modo mais ou menos banal e equivocada por atores pouco atentos e, consequentemente, pouco vivos. Neste caso, o eixo que move é confuso ou, pior ainda, inexistente, e, neste último, trata-se do movimento caótico. O conceito de treinamento para o ator, também é, muitas vezes, entendido como a mera reprodução formal de determinados procedimentos (o cerimonial citado em Ruffini (2000), à página 6 deste texto). Esta atitude leva ao agir cego e, agindo desse modo, o ator só se afasta a cada dia dos territórios vivos e sensíveis, assim como também se afasta das possibilidades de elaboração e percepção do sentido de unidade, indispensável ao ato. Há, ainda, outra interpretação superficial e equivocada sobre treinamento para o ator, na qual se confunde sensibilidade e vida com exaustão física sem sentido ou com a distração de si mesmo.

A atenção, a seriedade, o agir inteiro no presente e o senso crítico durante o processo criativo, são algumas das variantes individuais e necessárias na relação com o treinamento. Aprendemos com Grotowski a questionar sempre: "Que tipo de exercícios deveríamos fazer? Depende da relação criativa que vocês têm com o teatro" (Grotowski, 2007, p. 162).

Ao treinar, os atores que visam conscientemente o seu crescimento, a conquista e a exploração do estado criativo (em si e sobre si mesmo), exercitam e desenvolvem em seus treinos faculdades múltiplas em ação conjunta, como, por exemplo, a atenção, a concentração, a imaginação, a adaptação, a inteligência, o autodomínio (cênico), o senso crítico e a destreza psicofísica. A destreza pode ser observada pela disponibilidade do corpo inteligente e sensível em ação, e que é, em parte, consequência de certo tempo em treinamento, o qual exige condição específica: a sistematização, a crueldade e a sacralização no trabalho do ator.

A sacralização pode ser relacionada com certo valor que o ator atribui em seu trabalho. Este valor, quando atentamente semeado por cada ator, cresce e une, com sentido comum, os aspectos objetivos (como a disciplina, o rigor e a precisão) e os subjetivos (qualidade sutil e transcendente) de seu trabalho em constante desen- 
volvimento. É possível observar que o sentido proposto e vivenciado como sagrado, no corpo, e, portanto, no trabalho do ator, está fundamentado concretamente em sua continuidade prática; isto é, na transpiração de cada dia e em cada ator, em si e sobre si mesmo. Podemos incluir neste valor atribuído ao trabalho, o sagrado, um dos elementos psicotécnicos que Stanislávski denominou de fé cênica e sentido de verdade ${ }^{6}$.

A transpiração, os critérios, a fé cênica, a imaginação, o senso estético, os questionamentos, a inquietude, o contato com o medo, a elaboração da coragem, entre outros elementos, apontam o esforço indispensável, o empenho e a dedicação do ator-criador, e nos levam a evidenciar ainda mais que o sagrado, no trabalho do ator, não é uma fantasia7; mas sim os valores, os princípios e os procedimentos que, em ação conjunta, mobilizam o ator, razões estas que definem, principalmente, o como ele se move e o quanto ele quer crescer.

O sagrado, por conseguinte, não é uma abstração, mas certa qualidade sutil e encarnada; é uma atitude que possui dimensão espiritual - ética, estética e mitológica -, cuja vivência exige imaginação, disciplina, trabalho pesado e insistente. Em outras palavras, o sagrado também é a conexão com a dimensão que é reconhecida como conquista e recompensa, porque sempre que uma descoberta criativa acontece, ela vem com a sensação conjunta de que a criação nos foi dada, permitida ou revelada. A via negativa pode ser um caminho para a compreensão deste estado e desta visão porque é

um lugar onde não somos divididos. [...] Se cumprimos o ato com todo nosso ser, como nos instantes do verdadeiro amor chegará o momento em que será impossível decidir se agimos conscientemente, ou inconscientemente. Em que é difícil dizer se somos nós a fazer algo ou se isso nos acontece (Grotowski, 2007, p. 211).

Esta qualidade e dimensão poética tocam, ao nosso entendimento, a dimensão do mito. É que, segundo a psicologia junguiana,

a mentalidade primitiva não inventa mitos; ela os experimenta. Os mitos são revelações originais da psique pré-consciente... Muitos destes processos inconscientes podem ser ocasionados indiretamente pela consciência, mas jamais por deliberação consciente. Outros parecem surgir espontaneamente, isto é, de uma causa consciente não discernível ou demonstrável (Jung, 1953-1979 apud Sharp, 1997, p. 108).

Para Brook, o sagrado é apresentado como uma qualidade transcendente que abre, amplia e transforma, qualitativamente, aquilo que poderia ser comum e banal.

\footnotetext{
${ }^{6}$ Ver DAgostini, 2007.

${ }^{7}$ Sem o objetivo de dirigir uma estabilização semântica, mas, sim, para propor um sentido ao pensamento, cabe lembrar que Stanislávski já distinguiu, há quase cem anos, a imaginação da fantasia. Ensinou-nos que a primeira é um acontecimento psicofísico, um fenômeno que só acontece a partir de certo engajamento psicofisiológico (somático), isto é, a imaginação a qual nos referimos é faculdade sensível que emerge da realidade psicossomática e que também necessita da ação conjunta de outros elementos técnicos como, por exemplo, a atenção, a concentração, o tempo-ritmo, a relação, entre outros. Enquanto que a segunda, a fantasia, acontece sem o empenho corporal, ou seja, é um movimento oposto ao da imaginação como materialidade psicossomática porque se distancia da resposta corpo-
}

ral, e, por isso, atua mais como uma divagação da mente sem um correspondente vibrátil. Atenção, o que dissemos sobre a fantasia é que não há o engajamento vibrátil, poético e expressivo indispensável à linguagem cênica, e, neste caso, não podemos mais ver a cognição e a compreensão semântica dissociadas do corpo. Por fim, a diferença da imaginação em relação à fantasia, no contexto teatral, segundo Stanislávski, é que a primeira, indispensável ao ator-criador, necessita da elaboração da linguagem corporal, cênica, poética e expressiva enquanto que a fantasia estaria em um espaço mais privado sem expressividade e sem comunicação correspondentes. A fantasia seria um espaço caótico corporalmente, enquanto que a imaginação está firmemente aterrada, apropriada e ordenada (tempo-ritmo) em um território Corporal e espacial. 
Para tanto, "no tocante ao teatro sagrado o essencial é admitir a existência de um mundo invisível, que é preciso tornar visível" (Brook, 1999, p. 49). Este entendimento do sagrado, sobre certa realidade imanente também nos aproxima do conceito de mito, Campbell (2008) que será apresentado mais adiante. O sagrado, no trabalho do ator, também pode ser observado como certa resposta a um chamado diário, cuja voz o ator é incapaz ensurdecer; é uma voz que mobiliza ao agir, ao doar-se, e ao crescimento. Sob esta compreensão do sagrado em Brook, também estamos próximos das potências e das qualidades propostas pelo ritual e pela crueldade em Artaud:

O teatro é antes de tudo um ritual mágico, isto é, ligado a forças, baseado em uma religião, crenças afetivas, e cuja eficácia que se traduz em gestos, está ligada diretamente aos ritos do teatro que são o próprio exercício e a expressão de uma necessidade mágica espiritual (Artaud, 1976-1984 apud Quilici, 2004, p. 35).

A crueldade, a vida, a disciplina, o rigor, a conexão com o sagrado e a via negativa, libertam no corpo (trabalhado) do ator (que treina) qualidades mais sutis, a partir dos seus centros de energia. A conexão ativa destas qualidades sutis também pode ser identificada em outro conceito grotowskiano, o de verticalidade, porque estamos nos referindo a um fenômeno de ordem energética:

energias pesadas mas orgânicas (ligadas às forças da vida, aos instintos, à sensu-
alidade) e outras energias, mais sutis. A questão da verticalidade significa passar
de um nível assim chamado grosseiro - em certo sentido poderíamos dizer "co-
tidiano" - para um nível energético mais sutil. [...] Nesse ponto, dizer mais não
seria certo, indico simplesmente a passagem, a direção. [...] isto é em termos ener-
géticos, se aproxima da energia muito mais sutil - coloca-se também a questão de
descer trazendo de novo essa coisa sutil dentro da realidade mais comum, ligada
à "densidade" do corpo (Grotowski, 2007, p. 235).

O trabalho insistente, rigoroso e criterioso, ou ainda, a crueldade, pode ser aproximado do pensamento literário: das batalhas diárias do herói e, neste caso, um certo herói-ator em sua jornada investigativa em si e sobre si mesmo e, essencialmente, imaginada e criativa. Há, portanto, neste pensamento, um sentido maior que o move, o próprio pensamento, e por isso o ator pode ser visto, de certo modo, como um herói que atende a um chamado de forma incansável, na busca constante de vias de renovação.

Sobre esta possível inversão da percepção, a do chamado, Copeau também nos ensina que, para o ator, doar-se é tudo (Copeau, s/d). Grotowski, mais tarde, fala sobre o doar-se como atenção e concentração:

a concentração existe quando não a procuramos, quando nos devora algo que devemos fazer. Quando vocês amam alguém e fazem amor, pensam talvez na concentração? Aquilo que se faz é preciso fazê-lo até o fim. É preciso se dar inteiramente, superando as fronteiras da cotidianidade, de modo tangível, de verdade. Então existe a concentração. Quando existe doação, existe a concentração (Grotowski, 2007, p. 210).

A renovação, apontada anteriormente, se inicia no olhar do ator sobre e sob o trabalho cuja percepção é bem mais ampla do que a visual e individual; isto é, trata-se do enorme esforço para abrir mão e mover-se do espaço da percepção acostumada 
confortável e segura, e, consequentemente, erma. Trata-se da crueldade artaudiana cuja interpretação requer seriedade, critérios e imaginação. Estamos, por conseguinte, nos direcionando também ao território (psicofísico) dos afetos:

Não devemos entender esta palavra no seu sentido corriqueiro, ligado à expressão das emoções cotidianas, já que Artaud recusa-se a tratar das "paixões medianas". $\mathrm{O}$ "teatro da crueldade" não pretende trabalhar com as emoções decorrentes unicamente das relações que os homens estabelecem entre si, num contexto social e psicológico. A exemplo das tragédias antigas e dos mitos, trata-se de mobilizar uma certa qualidade de experiência, a "angústia que está na base de toda verdadeira poesia", que brota de confrontações metafísicas, e que para Artaud foram suprimidas do teatro ocidental moderno (Quilici, 2002, p. 97-98).

Estamos nos referindo à indispensável inquietação que mobiliza o Ser artista, isto é, o desconforto interior (psicofísico) que o move; e,

afeto é uma palavra que nos esclarece sobre a eficácia pretendida pelo teatro artaudiano. Ela designa uma espécie de poder de contágio, de capacidade que o teatro teria de afetar, inclusive organicamente, os que dele participam (Quilici, 2002, p. 98).

O doar-se, o ritual, a crueldade, inquietude e a dor, no agir, podem ser observados, ainda, por outra perspectiva; isto é, sob uma compreensão interior e mais ampla que esta fortemente vinculada a certa materialidade exterior. Esta materialidade autônoma Ruffini apresenta como vocação; ela é um chamado doloroso e indispensável.

Se estudarmos a história da vocação teatral estaremos indo em busca da nossa tradição. Estamos buscando aquilo que nos faz crescer, aquilo que nos impede de permanecermos sendo uma "moda juvenil". [...] a inclinação é diferente da vocação. A inclinação ou tendência é o que nos é fácil fazê-lo. [...] a tendência está dentro de nós, mas a vocação está fora de nós. Vocação vem de "vocare" que significa "chamar". [...] Distingo inclinação de vocação porque não interessa que os jovens tenham uma tendência para fazer teatro. Cada um que faça as contas consigo mesmo. O que é importante, ao invés, é a "vocação teatral", se alguma coisa do exterior chama você a fazer teatro, ou a olhá-lo, ou a estudá-lo, ou a viver num ambiente teatral. São formas diferentes da mesma realidade. A vocação é sempre dolorosa, mesmo que crie felicidade. A vocação vai contra a tendência. [...] A vocação se reconhece porque faz mal, dói. A inclinação se reconhece porque não faz mal. Essa é uma bússola importante. [...] Se não dói, ninguém nos chama (Ruffini, 2000, p. 53).

\section{O mito e sua função transcendente como materialidade psicossomática sen- sível e criativa na jornada do herói}

Para situar e ampliar um pouco mais o sentido de tradição e a dimensão heróica da qual nos aproximamos, como referência corporal, dos conceitos crueldade e sagrado no trabalho do ator, é preciso começar pelo pensamento mítico. Faremos isso a partir de determinados estudos comum a Keleman ${ }^{8}$ (2001) e Campbell (2001) sobre o mito e sua função transcendente, transformadora e corporificada na jornada do herói. 
Keleman (2001) define o corpo como mito e nos leva ao entendimento arquetípico ${ }^{9}$ de um destino somático que nos foi dado, e é na difícil vivência consciente desta jornada, a do destino, a da escuta e entrega ao chamado, que é proposto o caminho do herói como um meio organizador; ou seja, o mito.

Importa saber que "onde quer que exista uma imagem mítica, ela foi legitimada por décadas, séculos ou milênios" (Campbell, 2008, p. 18). Sob a perspectiva psicológica e energética estamos diante da energia viva no centro dos símbolos ${ }^{10}$, a qual os vem preservando vivos, e, em parte, indecifráveis por toda a esteira do tempo. Porém, é esta mesma energia, viva e em parte indecifrável, que move o eixo dos símbolos e apresenta direcionamentos a um caminho mítico. A expressão simbólica que estamos nos referindo é a referência corporal que emerge no Ser como experiência somática, como imagens que emergem do Corpo (do inconsciente) sob trabalho sensível, melhor seria dizer que emergem do self somático, do Corpo sensível e disponível a essa comunicação.

Esclarecemos ainda que mito "não é o mesmo que história. Os mitos não são histórias inspiradoras sobre pessoas que viveram uma vida notável. Não, o mito é o transcendente na relação com o presente" (Campbell, 2008, p. 18). É, portanto, deste modo, que "a eternidade não tem relação alguma com o tempo. O tempo é que exclui alguém da eternidade. A eternidade é o agora. É a dimensão transcendente do agora a que o mito se refere" (Campbell, 2008, p. 24).

O mito, segundo a psicologia junguiana, "é uma afirmação coletiva involuntária, baseada em uma experiência psíquica inconsciente" (Sharp, 1997, p. 107). Estamos, por conseguinte, com essa compreensão de mito (Campbell, Keleman e Jung), nos aproximando da materialidade viva, espiritual, imaginária, sensível e corporal a ser explorada psicofisicamente por cada um, em si e sobre si mesmo, a qual, vivência da materialidade, inclui uma jornada individual, inédita, e solitária. Mas, atenção, porque a jornada solitária indispensável ao crescimento e à transformação qualitativa não é, necessariamente, a ausência física de colegas na sala de trabalho ou em um espaço comum, mas, sim, a dimensão psíquica (psicossomática) e imaginária que se faz pelas conexões da atenção do ator com os conteúdos que emergem do seu self somático no momento em que trabalha.

Solidão é estar acompanhado, povoado, de certo dizer e de certa escuta, sobre si e a si mesmo, em estado poético: "é uma abertura para um mundo belo, para mun-

\begin{abstract}
${ }^{8} \mathrm{~S}$. Keleman, fundador da psicologia formativa, e J. Campbell, grande autoridade no pensamento mítico, estudaram juntos na forma de seminários que duraram quatorze anos. Eles conversaram ano a ano; o primeiro a partir da experiência do corpo e, o segundo, sob o pensamento mítico: símbolo e o significado. Assim, juntos chegaram ao tema Parsifal e o Santo Graal. Destes estudos foi editado Mito e Corpo.

9 ก nosso padrão básico de animação é um arquétipo. O corpo humano, um antigo padrão corporal, está sempre presente. $O$ padrão não é apenas a forma humana ereta, é também o padrão excitatório básico que experienciamos como o impulso de reproduzir, de estar junto, de formar hordas, nutrir, cuidar, cuidar dos outros. Mediante este padrão, temos empatia com todas as criaturas vivas. Nós nos reconhecemos nelas. No plano mais aparente da nossa vida, conhecemos o
\end{abstract}

corpo como forma pessoal, nós o vivenciamos como um mito familiar. "Seja como seu tio, os santos, os filósofos. Ou como um mito social. Seja educado, seja racional. Somos simultaneamente antigos e modernos" (Keleman, 2001, p. ${ }^{43}$ ).

10 O termo "Símbolo" deriva do grego symbállo, "coloco junto". Na literatura junguiana são fundamentalmente dois os usos do termo: I. FUNÇÃO SUBSTUTIVA DO SÍMBOLO; e II. FUNÇÃO FORMÅORA E TRANSFORMADORA DO SÍMBOLO (Ver Pieri, 2002, pp.458462). Símbolo, a melhor expressão possível para algo desconhecido (Sharp, 1997, p.146): "Toda expressão psicológica é um símbolo se pressupormos que declara ou significa algo mais e algo diferente dela própria, e que escapa ao nosso conhecimento atual" (Jung apud Sharp, 1997, p. 146). 
dos belos. Dá ao eu um não-eu que é o bem do eu: o não-eu meu. É esse não-eu meu que encanta o eu do sonhador e que os poetas sabem fazer-nos" (Bachelard, 2006, p.13). A solidão que procuramos é, também, consequência de um ato de coragem, é certa solidão viva e criativa que aproximamos da imaginação material bachelardiana cuja materialidade poética, a criação, reconhecemos em realidade psicossomática. A imaginação, segundo Bachelard, é um processo vivo no qual "se uma imagem presente não faz pensar numa imagem ausente, se uma imagem ocasional não determina uma prodigalidade de imagens aberrantes, uma explosão de imagens, não há imaginação" (Bachelard, 2001, p. 3). A imaginação, indispensável à criação, é, portanto, um processo maior; bem maior que o indivíduo. "A imaginação é, assim, um além psicológico" (Bachelard, 2001, p. 6). A solidão também é a vida e a conexão simultânea com o medo e com a coragem; ou seja, é a escuta das vozes vivas que emergem do self corporal, do inconsciente.

Campbell (2008), para falar sobre essa jornada (em si e sobre si mesmo) em sua dimensão e funções ${ }^{11}$, utiliza um romance arturiano e assim nos aproxima da imagem essencial na jornada no herói. Estamos nos referindo À busca do Santo Graal12.

Para compreendermos a constante busca por esta centelha de vida transformadora - a eternidade e o transcendente -, simbolicamente representada pelo numinoso Santo Graal, é preciso apresentar o pensamento mítico proposto por Keleman como o constante processo de corpar, isto é, de aprender como dar corpo a si mesmo para manter a continuidade e a vida no processo de individualidade, crescimento e amadurecimento.

Importa saber que Keleman (2001) revela a experiência da realidade mítica somática como certo caminho psicofísico indispensável à individualidade. Keleman investiga e estuda a subjetividade e a imaginação somática como dinâmica do corpar: "a experiência como um evento corporificado e o mito como um processo organizador, é um modo de criar ordem a partir da experiência somática" (Keleman, 2001, p. 17). E, por meio desta prática constante de corpar, que envolve dificuldades, equívocos, superações e essencialmente transformações, que entra, em paralelo, a jornada mítica de Parsifal cujo caminho vai do orgulho à compaixão.

O eixo dessa dinâmica transformadora, do orgulho à compaixão, é a busca pela

\begin{abstract}
11 Campbell, ao falar da necessidade dos ritos aponta quatro funções da mitologia viva. A primeira seria "conciliar a consciência com as preconições da sua própria existência - quer dizer, com a natureza da vida. [...] não a mera reconciliação entre a consciência e as precondições de sua própria existência, mas a reconciliação com a gratidão, o amor, o reconhecimento da delicadeza. Esta é a primeira função da mitologia: incutir em nós um sentido de deslumbramento grato e afirmativo diante do estupendo mistério que é a existência. A segunda função é apresentar uma imagem do cosmos, uma imagem do universo que nos cerca, que conserve e induza essa sensação de assombro. Podemos denominá-la função cosmológica da mitologia. A terceira função de uma ordem mitológica é validar e preservar dado sistema sociológico: um conjunto comum daquilo que se considera certo e errado [...] no qual esteja apoiada nossa unidade social particular. Por fim, a quarta função da mitologia é psicológica. O mito
\end{abstract}

deve fazer o indivíduo atravessar as etapas da vida, do nascimento à maturidade, depois à senilidade e à morte" (Campbell, 2008, pp. 34-37).

12 Há uma passagem nessa história em que todos os cavaleiros estão reunidos em volta da távola redonda do Rei Artur [...] O Santo Graal apareceu para os cavaleiros ali reunidos - não em toda sua glória, mas coberto por um tecido bonito, brilhante. Em seguida sumiu. [...] Gawin, sobrinho de Artur, disse: 'proponho que todos dessa companhia façamos um voto: sair em busca do Graal'. Eles acharam que seria uma desgraça partir em grupo. 'Cada qual entrou na Floresta Aventurosa em um ponto escolhido, onde fosse mais escuro e não houvesse caminho nem trilha'. Você entra na floresta no ponto mais escuro, onde não há uma trilha. Se existir caminho ou trilha será o caminho e a trilha de outra pessoa; cada ser humano é um fenômeno único. A ideia é encontrar o próprio caminho da bem-aventurança (Campbell, 2008, p. 27). 
integridade do processo somático cuja dinâmica se dá como em uma serpente; é uma "forma em movimento. Nas relações humanas a parte do nosso self que experiência nosso processo somático precisa confiar na contínua mutação da própria forma" (Keleman, 2001, p. 85). No mito de Parsifal, esse foi o seu equívoco, porque ele agiu em acordo com as regras sociais e ensurdeceu à voz de suas respostas viscerais ${ }^{13}$.

Importa esclarecer que essa jornada do herói pode ser ativada e percorrida como realidade psicossomática; ela é indispensável à individualidade, ou seja, é uma vivência peculiar no momento presente, mas também carrega em si mesma o sentido de eternidade. O que estamos querendo dizer é que a vivência mítica e arquetípica possui materialidade fisiológica, ela emerge da realidade celular com materialidade psíquica. O sentido de eternidade é uma realidade interior sutil (transparente) que é dada pelos conteúdos que emergem do inconsciente na forma de imagens corporificadas e que atuam como realidade psicossomática, e, principalmente, como um sentido organizador.

Segundo estudos conjuntos de Keleman e Campbell (2001), o caminho mítico, a descoberta mítica, se dá, em cada um, a partir dos centros de energia do corpo, os quais podem estar de modo mais ou menos ativados. "O mito faz você apontar o transcendente além do terreno do fenômeno. [...] A imagem de um deus pode assumir uma forma humana ou animal, mas sua referência transcende a isso" (Campbell, 2008, p. 19).

O herói de Campbell, segundo Keleman (2001), parte para uma jornada arquetípica e literária.

Cada um de nós é um herói. Isso é um dote. Temos um chamamento para a aventura. Recusamos. Segue-se uma crise. Não podemos voltar atrás - e atendemos o chamado. Juntamos auxiliares, professores, guias. E cruzamos o limiar do desconhecido. Perdemos a nossa identidade e afundamos num abismo, no nadir, na barriga da baleia. E emergimos. Começamos a viajar de volta para casa, para aquilo que conhecemos - cruzando de volta a fronteira. Nós voltamos. Transformados (Keleman, 2001, p. 19).

O mito, em Keleman,

pode transformar o que é transparente, o que é transcendente, no processo somático. O corpo usa seu cérebro para fazer imagens de si mesmo e do mundo. Essas experiências organizadas nos colocam em relação com o nosso corpo e o dos outros. É isso o que eu chamo de referência corporal e o que a literatura chama de pensamento mítico (Keleman, 2001, p. 105).

Deste modo, é no processo contínuo de aprender a ouvir e dialogar com o self corporal, o corpo como arquétipo e como destino psicossomático, que o trabalho se cria e se firma, cresce, ganha forma, vida e se renova continuamente.

13 Você confia no seu processo? Não no seu desejo, mas no seu processo, de tal modo que as suas respostas se manifestem e a sua mente corporal as suporte, em vez das regras sociais que lhe foram dadas. Você dá voz à sua compaixão ou lembra que os cavaleiros não fazem perguntas? Esse é o teste no qual Parsifal fracas- sa: o de emergir da natureza emocional. Parsifal intui ter respondido de maneira diferente do seu sentir interior. Então, ele se torna fiel ao seu processo corporal interno. Essa percepção de seu processo somático que o ajuda no seu caminho para a sua humanidade adulta (Keleman, 2001, p. 86). 
Para entendermos um pouco mais sobre o mito do Santo Graal como a jornada para habitar-se por si mesmo, como forma corporificada, e como certo processo de corpar, apresentaremos, também, o seu oposto, isto é, um corpo sem habitantes, um corpo que não vibra ou que vibra muito pouco. Um corpo rígido, ermo, e esvaziado de si mesmo. Isto quer dizer: o mito da terra devastada. Neste estado:

\footnotetext{
Nós existimos em uma terra devastada, onde as imagens vampirizam a vitalidade do soma, onde o pensamento está enamorado pelo próprio reflexo. Estamos vagando no deserto, sedentos e ressecados, porque as águas profundas do soma não estão mais ao nosso alcance. Vivemos na Terra Devastada, onde os nossos corpos existem apenas para os propósitos da mente (Keleman, 2001, p. 42).
}

Deste modo, o pensamento da psicologia formativa em diálogo com o pensamento mítico, nos leva ao entendimento que:

O nosso objetivo como seres individuais corporificados é manifestar o processo somático como uma experiência mítica. Ao perdermos a nossa realidade somática, tornamo-nos habitantes de uma terra de ninguém: o mito do corpo abandonado. Preencher-se novamente é o Graal (Keleman, 2001, p. 41).

\section{Estar no corpo é estar no presente}

Para entendermos um pouco mais sobre o mito em corpo ou o corpo como arquétipo ativo no momento presente, e como expressão do inconsciente, recorreremos ao pensamento junguiano que, por sua vez, nos apresenta a importância fundamental das relações vivas entre os opostos, no momento presente; ou seja, a correspondência dinâmica e indispensável entre os aspectos corporais e os psíquicos no Ser: "Qualquer coisa experimentada fora do corpo, num sonho, por exemplo, não é experimentada, a menos que a 'incorporemos', porque o corpo significa o aqui e agora" (Jung, 1930 apud Zimermann, 2009, p. 7).

Evocamos da psicologia profunda a compreensão sobre o fundamento do incorporar que nos leva ao entendimento de enraizamento somático (Keleman), no qual podemos ver certa correspondência com um princípio fundamental da antropologia teatral: as bases. Este princípio, no trabalho do ator, o enraizar-se, leva ao estado aterrar-se, o qual existe como conceito incorporado e também como imagem dinâmica e que pode tocar o sutil, a dimensão transparente. O enraizar-se é, portanto, um conceito, um princípio, um mito e uma imagem viva (dinâmica) com fins pedagógicos; logo, vital trabalho criativo do ator. Aprender constantemente como aterrar-se é um princípio vivo e que também tem relações com a cognição. "A individuação só pode ocorrer quando é percebida, quando alguém está lá e registra; de outro modo, é a eterna melodia do vento no deserto" (Jung, 1930 apud Zimermann, 2009, p. 13). $\mathrm{E}$, tanto na psicologia formativa (grounded) quanto na antropologia teatral (raízes, bases), como também na psicologia profunda, trata-se de uma compreensão psicossomática de aterrar-se em si mesmo no momento presente, a qual envolve diversas camadas em ação conjunta, que vão das raízes biológicas à energia sutil. Aterrar-se, portanto, é uma dinâmica que envolve os aspectos biológicos, tanto quanto os imaginários e os psíquicos, englobando ainda aquilo que emerge do inconsciente, sua 
motilidade e transformação até a transcendência (mito).

O espírito pode ser qualquer coisa, mas somente a terra pode ser algo definido. Então, manter-se fiel à terra significa manter-se em relacionamento consciente com o corpo. Não fujamos e não nos tornemos inconscientes dos fatos corporais, pois eles nos mantém na vida real e ajudam-nos a não perder nosso caminho no mundo das meras possibilidades, onde estamos simplesmente de olhos vendados (Jung, 1934/1939 apud Zimermann, 2009, p. 11).

Para retomar de forma mais clara o ponto de convergência deste pensamento que é o Corpo trabalhado e poético, evocamos a voz de Keleman (1999) ao dizer que: “C.G. Jung via o mito como parte da matriz biológica. Eu o defino como originário das células dos nossos tecidos, uma imagem não-linear governada pelo metabolismo corporal. [...] A vida no corpo é a fonte de nossos mitos" (Keleman, 1999, p. 61).

Para irmos adiante, até a tradição de si mesmo, em Ruffini (2000), falta-nos ainda unir e fundir ao Corpo como mito, como arquétipo, enraizado e vivo, a dimensão estética e plástica; isto é, a elaboração poética no trabalho do ator-criador: o Corpo como a criação.

Para encontramos tal caminho a essa possibilidade de aproximações, de compreensões e de entendimento e, ainda, para apontar um sentido à materialidade desta imaginação, em corpo, evocamos da fenomenologia bachelardiana a correspondência indispensável entre soma e psique em criação poética: é que "numa imagem poética a alma afirma sua presença" (Bachelard, 2005, p. 6).

A imagem torna-se um ser novo da nossa linguagem, expressa-nos tornando-nos aquilo que ela expressa - noutras palavras, ela é ao mesmo tempo um devir de expressão e um devir do nosso ser. Aqui a imagem cria o ser (Bachelard, 2005, p. 8).

Por fim, para desviar de certos equívocos, lembramos que tanto Bachelard quanto Jung, Artaud, Brook, Grotowski, entre outros, nos ensinaram que o ato poético - a criação - é suprapessoal (Jung, 1991), bem maior que a dimensão egoica, e é tanto no treinamento quanto no processo criativo que o ator exercita essa condição de saber como se concentrar e doar-se àquilo que é maior do que ele mesmo, voltando à afirmação: "A imaginação é um além psicológico" (Bachelard, 2001, p. 06) aproximando-a, desta vez, das reflexões de Brook (1995):

um ator tem que esquecer de "causar" impressão", de se "mostrar", de "fabricar", de "produzir efeitos", deve afastar-se da concepção de que ele está presente enquanto objeto em exposição. Essa ideia tem que ser substituída por outra noção, a de ser um servidor de uma imagem que sempre será maior do que ele próprio (Brook, 1995, p. 309).

\section{A criação e a tradição de si mesmo}

O pensamento mítico (Keleman e Campbell) sobre a referência corporal como enraizamento somático da imaginação, do mito e do Ser, em paralelo com o pensamento de Franco Ruffini sobre a tradição e a vocação, nos leva a ampliar o pensamento e o entendimento do trabalho criativo do ator, a criação, a partir da tradição de si mesmo. Este entendimento vincula a tradição de si mesmo aos treinamentos 
dinâmicos, críticos, sensíveis, mutantes e vivos. Isto quer dizer que:

Você só é apaixonante se chega com alguém, habitado por alguém, invadido por alguém, a serviço de alguém. Deveríamos saber que é, contudo, Ésquilo a pessoa importante. É ele que nos dá o pão cotidiano do corpo, no sentido material do termo e da alma (Mnouchkine, 1992 apud Féral, 2010, p. 140).

Estamos, portanto, aproximando o pensamento mítico encontrado na literatura, na biologia da psicologia formativa (psicossomática) e nas equivalências entre corpo e psique da psicologia profunda (no processo de individuação) da jornada do ator, ou seja, do constante trabalho do ator sobre si mesmo (crueldade) quando em estado criativo (criação), em si e sobre si mesmo, e que é indispensável à dinâmica artaudiana que Ruffini (2000) definiu como a tradição de si mesmo,

isto é, a tradição, tem um nome solene, mas verdadeiro, que é a liberdade do ator. E eu penso que também a liberdade do ser humano. $O$ ator não pode fazer o que ele quer, porque então seria o caos. $\mathrm{O}$ artista deve aprender a querer aquilo que faz, a fazê-lo criativamente, como para cada um de nós. [...] Isto é, inventando a sua liberdade. [...] um gesto responsável e construtivo. Se o ator consegue fazer isso, não só ensina algo importante a si mesmo, mas, uma vez ainda, através do teatro, ensina algo importante para a vida (Ruffini, 2000, p. 59).

Tais aproximações visam gerar espaços para movimentar o corpo-pensamento sobre o estado poético, a criação em corpo-ator. Esta expressão, estado poético em corpo-ator, nos levaria a pressupor e imaginar certa percepção e atenção correspondentes - psíquica e espiritual -; isto é, o desenvolvimento e a vivência de uma consciência sensível, suprapessoal, criativa e poética (psicossomática), ativa quando em estado e/ou processo criativo. Localizamo-nos, portanto, na realidade da imaginação material14 (Pessanha in Bachelard, 1985, p. xii) Este conceito, imaginação material, transposto à criação do ator engloba a realidade movediça, efêmera, psicossomática, criativa, sensível e sutil cuja materialidade é, segundo Stanislávski, necessariamente, orgânica e precisa.

A imaginação, segundo Stanislávski, é justamente o contrário do lugar-comum. Não se alimenta tirando o freio à fantasia, mas, ao contrário, pondo-lhe freios continuamente; nisto consiste o caminho da precisão; não serve para se perder em um outro mundo mas, entrar, e situar-se no outro mundo, da ficção (Ruffini, 2003 apud Dagostini, 1997).

Ainda assim, depois de tais aproximações de diferentes vertentes de conhecimento, resta o grande mistério, a potência viva e inconsciente que move o Ser e que é, portanto, o eixo e a força do trabalho criativo e poético. Esta imensa e misteriosa potência criadora, Shakespeare, nas palavras de Copeau, definiu como monstruosa.

Shakespeare disse (Hamlet, ato II, cena II) que a natureza do ator vai contra a natureza, que ela é horrível e ao mesmo tempo admirável. Ele o disse em uma só palavra: "Monstrous". O que é horrível, no ator, não é uma mentira, pois ele

${ }^{14}$ A imaginação material, por conseguinte, trata-se de
"passar, fenomenologicamente, para imagens não-vivi-
das, para imagens que a vida não prepara e que o poeta cria. Trata-se de viver o não-vivido e de abrir-se para uma abertura de linguagem" (Bachelard, 2005, p. 14). 
não mente. Não é um engodo, pois ele não engana. Não é uma hipocrisia, pois ele aplica sua monstruosa sinceridade em ser aquilo quem ele não é, e não em exprimir o que ele não sente, mas em sentir o imaginário. O que perturba o filósofo Hamlet, [...] da mesma forma que suas outras aparições dos infernos, é, em um ser humano, o desvio das faculdades naturais para um uso fantástico (Copeau: $\mathrm{s} / \mathrm{d})^{15}$.

Por fim, querendo este texto inteiro dizer que:

A tradição, então, que Artaud localiza é a tradição do próprio corpo em si mesmo. Mas não o corpo como Deus ou a mãe nos deu, mas o corpo trabalhado. Vou dizer uma palavra que vocês não gostarão, mas que é a verdade pura - um corpo colonizado, com força, com exercício, longo, doloroso e também tedioso. Até que esse corpo se torne uma outra natureza, uma segunda natureza. Não é a mesma coisa que se faz na vida cotidiana. Mas, ao mesmo tempo, não é totalmente diverso, é um outro nível da natureza (Ruffini, 2000, p. 57).

Com esta breve reflexão, propomos gerar espaços que possibilitem movimentar e provocar o pensamento sobre o significado e o sentido (mutantes) de treinamento para o ator, tanto quanto para o olhar atento e sensível sobre o significado e o sentido de Corpo em imaginação (como conteúdos que emergem do self somático e ganham um tratamento plástico e poético) e do Corpo como criação.

\section{Referências}

ARTAUD, Antonin. O Teatro e seu Duplo. São Paulo: Martins Fontes, 1999.

.1947 apud QUILICI, Cassiano. Antonin Artaud: Teatro e Ritual. São Paulo: Annablume; Fapesp, 2004.

Oeuvres Complètes Tomo I a XXV, Paris, Gallimard, 1976-1984 apud QUILICl, Cassiano. Antonin Artaud: Teatro e Ritual. São Paulo: Annablume; Fapesp, 2004.

BACHELARD, Gaston. L'air et les songes. Essai sur l'imagination du mouvement. 2ª . ed., 3 réimpression. Paris: José Corti, 1950.

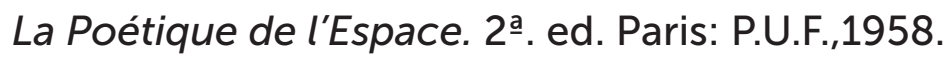

A Poética do Espaço. São Paulo: Martins Fontes, 1993.

A Poética do Devaneio. São Paulo: Martins Fontes, 1996.

A Intuição do Instante. Campinas-SP: Versus Editora, 2007.

15 In: www.grupotempo.com.br, consultado em: 30/ maio/2011. 
. A Psicanálise do Fogo. São Paulo: Martins Fontes, 2008.

. O Ar e os Sonhos: Ensaio sobre a Imaginação do Movimento.

São Paulo: Martins Fontes, 2001.

O Direito de Sonhar. São Paulo: DIFEL, 1985.

BARBA, Eugenio \& SAVARESE, Nicola A Arte Secreta do Ator: Dicionário de Antropologia Teatral. Campinas: Ed. Unicamp, 1995.

BROOK, Peter. O Ponto de Mudança. Rio de Janeiro: Civilização Brasileira, 1995.

A Porta Aberta. Rio de Janeiro: Civilização Brasileira, 1999.

CAMPBELL, Joseph. Mito e Transformação. São Paulo: Agora, 2008.

COPEAU, Jacques. Aos Atores. Disponível emhttp://www.grupotempo.com.br/tex_ aos_atores.html. Acesso em: 22/05/2011.

DAGOSTINI, Nair. O método de análise ativa de K. Stanislávski como base para a leitura do texto e da criação do espetáculo pelo diretor e ator. São Paulo, 2007 (Tese de Doutorado). Faculdade de Filosofia, Letras e Ciências Humanas/USP.

FÉRAL, Josette. Encontros com Ariane Mnouchkine: erguendo um Monumento ao Efêmero. São Paulo: Edições SESC SP, 2010.

FERREIRA, E. E. A. Dicionário de Imagens, Símbolos, Mitos, Termos e Conceitos bachelardianos. Londrina: EDUEL, 2008.

GROTOWSKI, Jerzy. O Teatro Laboratório de Jerzy Grotowski 1959-1969 / textos e materiais de Jerzy Grotowski e Ludwik Flazen; com um escrito de Eugênio Barba; curadoria de Ludwik Flazen e Carla Pollastrelli; com a colaboração de Renata Molinari. Tradução de Berenice Raulino. São Paulo: Perspectiva: SESC; Pontedera, IT: Fondazione Pontedera Teatro, 2007.

JUNG, Carl Gustav. O Espírito na Arte e na Ciência. Petrópolis: Vozes, 1991.

The Colected Works, 20 vls. Bollingen Series XX, traduzido por R.F.C. Hull, organizado por H. Read, M. Fordham, G. Adler e Wm. McGuire, Princeton University Press, Princeton, 1953-1979 apud SHARP, Daryl. O Léxico junguiano. São Paulo: Cultrix, 1997.

KELEMAN, Stanley. Anatomia Emocional. São Paulo: Summus, 1992. 
. O Corpo diz sua Mente. São Paulo: Summus, 1996.

. Viver o seu Morrer. São Paulo: Summus, 1997.

Mito e Corpo. Uma Conversa com Joseph Campbell. Trad. Denise Maria Bolanho. São Paulo: Summus, 2001.

MNOUCHINE, Ariane. Encontro público do Soleil com as escolas de teatro: um grupo começa com um sonho. Universidade de Quebéc - Montreal 06/11/1992 apud Féral, SESC, 2010.

MÜLLER, Lutz. O Herói. São Paulo: Cultrix, 1997.

PESSANHA, José Américo (Introdutor). In BACHELAR, Gaston. O Direito de Sonhar. São Paulo: DIFEL, 1985.

PIERI, Paolo. Dicionário Junguiano. São Paulo: Paulus, 2002.

QUILICl, Cassiano. S. Antonin Artaud: o ator e a física dos afetos. Revista Sala Preta, ECA, USP, São Paulo, n. 2, 2002.

. Antonin Artaud: Teatro e Ritual. São Paulo: Annablume; Fapesp,

2004.

RUFFINI, Franco. "Sistema" de Stanislávski. In: BARBA, Eugenio e SAVARESE, Nicola. A Arte Secreta do Ator. Dicionário de Antropologia Teatral. Campinas, Hucitec, 1995.

. A mente dilatada. In: BARBA, Eugenio e SAVARESE, Nicola. A Arte Secreta do Ator. Dicionário de Antropologia Teatral. Campinas, Hucitec, 1995.

. Conferência proferida no Seminário Internacional Teatro em Fim de Milênio. Tradução e transcrição de Ricardo Ponti, Maria Lúcia Raimundo e Nair Dagostini. Rio Grande do Sul, UFRGS: 2000.

Stanislavskij: Dal Lavoro dell'attore al Lavoro su di Sé. Roma: Laterza, 2003.

SAMUELS, A. et al. Dicionário Crítico de Análise Junguiana. Trad. de Pedro Ratis e Silva. Rio de Janeiro, Imago, 1988. Disponível em: <http://www.rubedo.psc.br/dicjung/ verbetes/corpo.htm>. Acesso em: 30 maio 2011.

SHARP, Daryl. O Léxico Junguiano. São Paulo: Cultrix, 1997.

STANISLÁVSKI, Konstantin. El Trabajo del Actor sobre Sí mismo en el Proceso Creador 
de las Vivencias. Buenos Aires-Argentina: Quetzal, 1980.

El Trabajo del Actor sobre Sí mismo en el Proceso

Creador de la Encarnación. Buenos Aires-Argentina: Quetzal, 1983.

El Arte Escénico. Madrid-España: Siglo Veintiuno de

España Editores, 2003.

STEVES, A. (1982), Archetype: A Natural History of the Self, Routledge \& Kegan Paul, London apud SAMUELS, A. et al. Dicionário Crítico de Análise Junguiana. Trad. de Pedro Ratis e Silva. Rio de Janeiro, Imago, 1988. Disponível em: <http://www.rubedo. psc.br/dicjung/verbetes/corpo.htm>. Acesso em: 30/05/2011.

ZIMMERMANN, Elizabeth (Org.) Corpo e Individuação. Petrópolis, Rio de Janeiro: Vozes, 2009.

\section{Endereços eletrônicos:}

http://www.rubedo.psc.br/dicjung/verbetes/corpo.htm. Acesso em: 30 maio 2011. www.grupotempo.com.br. Acesso em: 30 maio 2011.

Recebido em: 18/08/2014 Aprovado em: 14/09/2014 